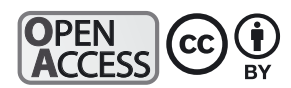

\title{
Elevated accumulation of the toxic metal mercury in the Critically Endangered oceanic whitetip shark Carcharhinus longimanus from the northwestern Atlantic Ocean
}

\author{
James Gelsleichter ${ }^{1, *}$, Graceann Sparkman ${ }^{1}$, Lucy A. Howey ${ }^{2,3}$, Edward J. Brooks ${ }^{4}$, \\ Oliver N. Shipley ${ }^{5}$ \\ ${ }^{1}$ University of North Florida, 1 UNF Dr, Jacksonville, FL 32224, USA \\ ${ }^{2}$ Johns Hopkins University, 100 International Dr., Baltimore, MD 21202, USA \\ ${ }^{3}$ Haiti Ocean Project, \#10, Dupuy 1, Petite Riviere de Nippes, Haiti \\ ${ }^{4}$ Cape Eleuthera Institute, Eleuthera, The Bahamas \\ ${ }^{5}$ School of Marine and Atmospheric Sciences, Stony Brook University, Stony Brook, NY 11794, USA
}

\begin{abstract}
The oceanic whitetip shark Carcharhinus longimanus is a widely distributed large pelagic shark species once considered abundant in tropical and warm temperate waters, but recently listed as Critically Endangered by the IUCN due to drastic population declines associated with overfishing. In addition to risks posed to its populations due to overexploitation, oceanic whitetip sharks are also capable of accumulating elevated quantities of harmful environmental toxicants, placing them at special risk from anthropogenic pollution. Herein, we provide the first data on accumulation of the toxic, non-essential metal mercury (Hg) in northwest Atlantic (NWA) oceanic whitetip sharks, focusing on aggregations occurring at Cat Island, The Bahamas. Total Hg (THg) concentrations were measured in muscle of 26 oceanic whitetip sharks and compared with animal length and muscle $\delta^{15} \mathrm{~N}$ to evaluate potential drivers of $\mathrm{Hg}$ accumulation. THg concentrations were also measured in fin and blood subcomponents (red blood cells and plasma) to determine their value as surrogates for assessing $\mathrm{Hg}$ burden. Muscle THg concentrations were among the highest ever reported for a shark species and correlated significantly with animal length, but not muscle $\delta^{15} \mathrm{~N}$. Fin, red blood cell, and plasma THg concentrations were significantly correlated with muscle THg. Fin THg content was best suited for use as a surrogate for estimating internal Hg burden because of its strong relationship with muscle THg levels, whereas blood THg levels may be better suited for characterizing recent $\mathrm{Hg}$ exposure. We conclude that $\mathrm{Hg}$ poses health risks to NWA oceanic whitetip sharks and human consumers of this species.
\end{abstract}

KEY WORDS: Oceanic whitetip shark $\cdot$ Carcharhinus longimanus $\cdot$ Mercury $\cdot$ Ecotoxicology

\section{INTRODUCTION}

Large predatory sharks often accumulate higher quantities of the highly toxic, non-essential metal mercury $(\mathrm{Hg})$ than most marine fishes due to their large size, long lifespan, and high trophic position (Zillioux 2015, Bosch et al. 2016). This is particularly true for

${ }^{*}$ Corresponding author: jim.gelsleichter@unf.edu pelagic or open ocean shark species, which have been shown to demonstrate muscle $\mathrm{Hg}$ concentrations that can be 2- to 3-fold higher than those observed in large coastal sharks of similar size and trophic position (e.g. bull sharks Carcharhinus leucas, Le Bourg et al. 2019). With the exception of some bathyal species, which may accumulate greater-than-anticipated

(C) The authors 2020. Open Access under Creative Commons by Attribution Licence. Use, distribution and reproduction are unrestricted. Authors and original publication must be credited. 
levels of $\mathrm{Hg}$ due to factors other than size and predatory habits (e.g. proximity to active volcanism, higher rates of $\mathrm{Hg}$ methylation and bioavailability of organic monomethylmercury [MeHg] in the deep sea), pelagic sharks generally possess the highest Hg levels observed in marine fishes (Le Bourg et al. 2019). For some species, relative concentrations can average as high as $3 \mathrm{mg} \mathrm{kg}^{-1}$ wet weight (WW) (e.g. shortfin mako Isurus oxyrinchus; Biton-Porsmoguer et al. 2018). The high Hg content of shark meat can pose significant risks to the health of human seafood consumers since certain pelagic sharks are among the most highly valued species in the commercial seafood market owing to the high quality of their meat and fins (Campana et al. 2005, Byrne et al. 2017). It also poses potential threats to the health of these species themselves as well as to the well-being of their populations, many of which have already been shown to be in decline because of overfishing, particularly in the commercial sector (Dulvy et al. 2008).

It has been hypothesized that the oceanic whitetip shark Carcharhinus longimanus, one of the most critically threatened yet poorly studied pelagic sharks (Howey-Jordan et al. 2013, Tolotti et al. 2015), may be uniquely prone to accumulating elevated levels of $\mathrm{Hg}$, putting it at special health risks from the potential effects of this toxicant. This was initially suggested based on a single measurement of the highly toxic $\mathrm{MeHg}$ in oceanic whitetip fin tissue, which at $0.530 \mathrm{mg} \mathrm{kg}^{-1}$ dry weight (DW) was the fourth highest concentration observed out of 13 large shark species, including apex predator species such as shortfin mako sharks and white sharks Carcharodon carcharias (Nalluri et al. 2014). More recently, this hypothesis has been strengthened by observations of total $\mathrm{Hg}$ ( $\mathrm{THg}$ ) concentrations in muscle of oceanic whitetip sharks from the southwestern Indian Ocean, which averaged $7.14 \pm 7.44 \mathrm{mg} \mathrm{kg}^{-1} \mathrm{DW}\left(\sim 2 \mathrm{mg} \mathrm{kg}^{-1}\right.$ WW based on $70 \%$ moisture, Bergés-Tiznado et al. 2015), exceeding levels in all other large pelagic shark species collected from the same location including the shortfin mako $\left(5.96 \pm 2.78 \mathrm{mg} \mathrm{kg}^{-1} \mathrm{DW}\right.$, Kiszka et al. 2015). However, no studies to date have examined $\mathrm{Hg}$ accumulation in oceanic whitetip sharks from the northwestern Atlantic (NWA) Ocean. It is important to determine whether $\mathrm{Hg}$ accumulation poses risks to oceanic whitetip shark populations in NWA waters, especially since significant population declines in this region, due primarily to high incidental bycatch in commercial fisheries, have resulted in the population being listed as Critically Endangered (Rigby et al. 2019, Young \& Carlson 2020).
In this study, we examined $\mathrm{Hg}$ accumulation in oceanic whitetip sharks from NWA waters focusing on a known aggregation site for this species at Cat Island, The Bahamas (Howey-Jordan et al. 2013, Madigan et al. 2015, Howey et al. 2016). THg concentrations were measured in the muscle tissue of oceanic whitetip sharks and compared with those reported in other large pelagic sharks from NWA waters to examine species-specific differences in $\mathrm{Hg}$ accumulation. In addition, we examined associations between $\mathrm{THg}$ concentrations in muscle tissue and those in fin, red blood cells, and plasma to assess the efficacy of these tissues for evaluating $\mathrm{Hg}$ exposure and uptake in this species and other sharks. Associations between THg concentrations and stable isotope ratios of nitrogen $\left(\delta^{15} \mathrm{~N}\right)$, a commonly used proxy for fish trophic position, were also examined in muscle to evaluate the effects of trophic activity on $\mathrm{Hg}$ accumulation. Last, associations between indicators of recent $\mathrm{Hg}$ uptake and $\delta^{15} \mathrm{~N}$ in plasma, a proxy for assessing recent dietary habitats, were also examined.

\section{MATERIALS AND METHODS}

\subsection{Study location and animal collections}

Research was conducted under permits MAF/FIS/ 17 and MAF/FIS/34 from the Bahamian Department of Marine Resources. Animal sampling protocols followed that of the UK Home Office Animals Act and guidelines of the Association for the Study of Animal Behavior and Animal Behavior Society (Rollin \& Kessel 1997).

Sharks were sampled in May of 2017 at Cat Island, The Bahamas (Fig. 1), using methods previously described by Howey-Jordan et al. (2013) and Madigan et al. (2015). Sharks were attracted to the sampling site using a chum crate containing fresh pieces of dolphinfish Coryphaena hippurus or Atlantic bonito Sarda sarda. Sharks were captured using baited handlines (for full details of capture methodology, see Howey-Jordan et al. 2013) and secured alongside the research vessel using a head and tail rope. Animals were then sexed based on the presence or absence of the external male intromittent organs, the claspers (Clark \& von Schmidt 1965). Three length measurements were measured to the nearest $\mathrm{cm}$ using a tape measure: pre-caudal length (PCL), fork length (FL), and stretched total length (STL); FL was most commonly used in the present study. Stage of sexual maturity was determined based on comparison of 


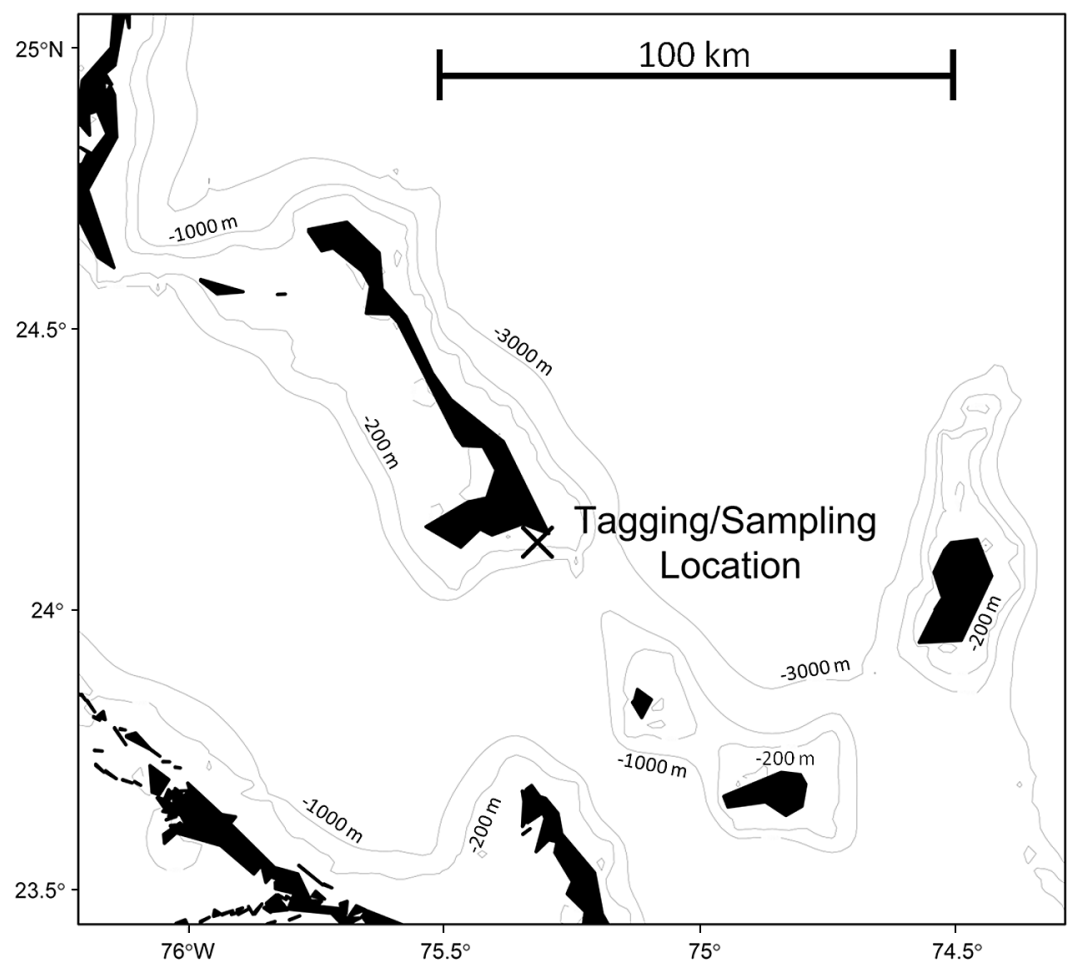

Fig. 1. Location of the study area at Cat Island, The Bahamas (modified from Madigan et al. 2015)

animal length with previously published estimates of size-at-maturity for oceanic whitetip sharks in the Atlantic Ocean (180 to $190 \mathrm{~cm}$ total length [TL] for both sexes, Lessa et al. 1999). Maturity status was also confirmed in several individuals by determining pregnancy status using an Ibex Pro portable ultrasound (E.I. Medical Imaging) equipped with a 5 to $2.5 \mathrm{mHz}$ curved linear array transducer capable of scanning $24 \mathrm{~cm}$ in depth, as part of a separate study on reproduction (Madigan et al. 2015). Approximately $1 \mathrm{~g}$ of white muscle tissue was excised from the dorsal musculature using a modified $10 \mathrm{~mm}$ Parisienne scoop (Deglon). Small fin biopsies were generally taken from the free rear tip of the dorsal or anal fins, or from the pelvic fin, and stored on ice. Blood samples were collected via caudal venipuncture using sterile syringes and 16 gauge needles, transferred to sterile blood collection tubes lined with lithium heparin anticoagulant, and temporarily stored on ice. Upon returning to the laboratory, blood was centrifuged at $1500 \times g$ for 5 min to separate plasma and red blood cells. Samples were then frozen at $-20^{\circ} \mathrm{C}$. We assumed that stable isotope value ratios were unaffected by the sodium heparin anticoagulant, based on findings of previous studies (Weideli et al. 2019).

\subsection{Stable isotope analysis}

Muscle, fin, red blood cell, and plasma samples were oven dried at $60^{\circ} \mathrm{C}$ and homogenized to a fine powder using a mortar and pestle. Samples were initially processed for stable isotope analysis for a separate study on trophodynamics; however, only data on muscle and plasma $\delta^{15} \mathrm{~N}$ were used in the present study as indicators of trophic position and recent trophic activity, respectively. Due to the potential effects of isotopically light nitrogenous compounds (e.g. urea and trimethylamine $\mathrm{N}$-oxide) on $\delta^{15} \mathrm{~N}$ values, muscle samples were triple rinsed with deionized water (Carlisle et al. 2017, Shipley et al. 2017). No chemical treatment was applied to plasma samples, based on recommendations of Kim \& Koch (2012). Approximately 250 to $350 \mu \mathrm{g}$ of ground tissue was weighed into tin capsules and combusted using a Thermo Scientific Delta V Plus continuous flow isotope ratio mass spectrometer coupled to an Isolink Elemental Analyzer (EAIRMS) at the Department of Geosciences, for Earth and Planetary Science, Stony Brook University.

Stable isotope abundances were expressed in delta notation $(\delta)$ as the deviation from standards in parts per thousand (\%) using the following equation: $\delta X=$ $\left[\left(R_{\text {sample }} / R_{\text {standard }}\right)-1\right] \times 1000$ where $X$ is ${ }^{15} \mathrm{~N}$ and $R$ is the ratio ${ }^{15} \mathrm{~N} /{ }^{14} \mathrm{~N}$. Samples were reported relative to atmospheric nitrogen. Instrument drift and analytical precision were examined by analysis of certified reference standards of glycine (USGS65, $\mathrm{n}=24$ ), glutamic acid (IU L-glutamic acid, $\mathrm{n}=22$ ), caffeine (IAEA-600, $\mathrm{n}=8$ ), and an in-house working standard of urea (IVA urea, $n=9$ ), which were placed at the beginning and end of every run, as well as in between every 5 samples. For all standards across all runs, analytical error (SD) did not exceed 0.35 for $\delta^{15} \mathrm{~N}$.

\subsection{THg analysis}

THg concentrations in oceanic whitetip muscle, fin, red blood cells, and plasma were determined via thermal decomposition (combustion), amalgamation, and atomic absorption spectrometry using a calibrated DMA-80 Direct Mercury Analyzer (Milestone), following EPA (Environmental Protection Agency) 
Method 7473 (US EPA 2007). Dried and crushed samples previously prepared for stable isotope analysis were used to measure THg concentrations in muscle, fin, and red blood cells, whereas plasma THg concentrations were determined using liquid aliquots not previously prepared for stable isotope analysis. Approximately $0.05 \mathrm{~g}$ of crushed muscle, fin, or red blood cell samples or $100 \mu \mathrm{l}$ of plasma were loaded into the DMA-80 and analyzed for THg following protocols established by Nam et al. (2011). Quality control procedures included analysis of laboratory method blanks, duplicate tissue samples, and certified reference materials (Coal Fly Ash, SRM 1633c and San Joaquin Soil, SRM 2709a, National Institute of Standards and Technology) for each group of 10 samples analyzed following the guidelines outlined in US EPA (2007). Precision of duplicate samples averaged $4.33 \%$.

As muscle, fin, and red blood cell samples were initially collected for stable isotope analysis rather than THg measurements, data on moisture content was not collected during the drying stage. Due to this, THg concentrations in muscle, fin, and red blood cells were reported in DW. However, data on muscle THg concentrations were also converted to WW using the average percent moisture of muscle observed in previous shark Hg studies $(70 \%$, Bergés-Tiznado et al. 2015) so that the current findings could be compared with threshold levels for seafood consumption and toxicity, as well as those from other sharks that have been reported on a WW basis. Conversion of DW measurements of THg in fin and red blood cells was not possible due to lack of prior published data on moisture content in these tissue matrices. Plasma $\mathrm{THg}$ concentrations were expressed in $\mu g \mathrm{l}^{-1}$, as in past studies (e.g. Merly et al. 2019).

\subsection{Data analysis}

Data were separated by tissue type and analyzed using descriptive statistics to determine mean $\mathrm{THg}$ concentrations for comparison with previous studies on NWA sharks. Patterns of Hg accumulation were examined by using Pearson's correlation coefficient to determine if there was a significant correlation between muscle THg concentrations and FL, which was used as a proxy for age. Correlations between FL and $\mathrm{THg}$ concentrations in other tissue types were also analyzed to determine if $\mathrm{Hg}$ levels in these tissues appeared to reflect long-term $\mathrm{Hg}$ accumulation patterns. Pearson's correlation coefficient was used to determine if there was a significant correlation between $\mathrm{THg}$ concentrations and $\delta^{15} \mathrm{~N}$ in muscle.
The value of using $\mathrm{THg}$ concentrations in fin, red blood cells, and plasma as indicators of internal $\mathrm{Hg}$ burden was evaluated by using Pearson's correlation coefficient to determine if there were significant correlations between these values and those measured in muscle using natural log-transformed data. Linear regression analysis was also performed on these datasets to determine the strength of the relationships between variables. Last, since vertebrate blood $\mathrm{Hg}$ is generally considered to reflect both recent (days to weeks) exposure along with a more stable component associated with long-term accumulation patterns, a measure known as the Index of Recent Exposure (IRE) was calculated following the approach described by Day et al. (2005). The IRE for each individual shark was equal to the residual value from the linear regression between plasma and muscle THg concentrations and was considered to represent recent $\mathrm{Hg}$ uptake relative to long-term exposure for that individual (Day et al. 2005). Therefore, positive IRE values would be considered to represent elevated recent uptake compared with long-term exposure, whereas negative IRE values would reflect lowered recent uptake. Pearson's correlation coefficient was used to determine if there was a significant correlation between IRE values and plasma $\delta^{15} \mathrm{~N}$, using the latter as an indicator of recent dietary habits. This approach tested whether recent exposure of $\mathrm{Hg}$ was associated with recent feeding events. All statistical analyses were performed using SPSS software, v. 26.0 (IBM). All datasets fulfilled the assumptions of normality and homoscedasticity, supporting use of parametric analysis; however, data were natural log-transformed for evaluating correlations between $\mathrm{Hg}$ concentrations in muscle and other tissues to improve linearity.

\section{RESULTS}

A total of 26 oceanic whitetip sharks were examined in the present study. All individuals were determined to be sexually mature females based on absence of claspers and comparison of their length (range = 194-307 cm STL, mean $\pm \mathrm{SD}=248.2 \pm 29.8 \mathrm{~cm}$ ) with previously published estimates of size-at-maturity. Maturity status was also confirmed for most females using ultrasonography, as 23 of the 26 individuals were determined to be pregnant at the time of capture. Samples of all tissue types were not available for all individuals; therefore, sample sizes for different sample matrices and for correlation analyses varied. 
THg concentrations ranged from 6.19 to $37.35 \mathrm{mg} \mathrm{kg}^{-1}$ DW in muscle, not detectable (nd) to $1.67 \mathrm{mg} \mathrm{kg}^{-1} \mathrm{DW}$ in fin, 0.05 to $4.31 \mathrm{mg} \mathrm{kg}^{-1} \mathrm{DW}$ in red blood cells, and nd to $38.76 \mathrm{\mu g} \mathrm{l}^{-1}$ in plasma. Mean THg concentrations $( \pm$ SD) in all tissues are presented in Table 1. All muscle samples analyzed were found to have THg con-

Table 1. Total mercury concentrations in muscle, fin, red blood cells $\left(\mathrm{mg} \mathrm{kg}^{-1} \mathrm{DW}\right)$ and plasma $\left(\mu \mathrm{g} \mathrm{l} \mathrm{l}^{-1}\right.$ ) of mature female oceanic whitetip sharks Carcharhinus longimanus from Cat Island, The Bahamas. Sample size (n) is provided. Values are also presented in wet-weight basis $\left(\mathrm{mg} \mathrm{kg}^{-1} \mathrm{WW}\right)$ for muscle for comparison with other studies. nd: not detectable

\begin{tabular}{|lccc|}
\hline Tissue & $\mathrm{n}$ & $\begin{array}{c}\text { Mean } \pm \mathrm{SD} \\
\text { (Range) }\end{array}$ & $\begin{array}{c}\text { Mean } \pm \mathrm{SD}(\mathrm{WW}) \\
\text { (Range) }\end{array}$ \\
\hline Muscle & 24 & $\begin{array}{c}16.80 \pm 8.39 \\
(6.19-37.35)\end{array}$ & $\begin{array}{c}5.04 \pm 2.52 \\
(1.86-11.20)\end{array}$ \\
Fin & 21 & $\begin{array}{c}0.54 \pm 0.45 \\
(\mathrm{nd}-1.67)\end{array}$ & \\
Red blood cells & 22 & $\begin{array}{c}1.80 \pm 1.20 \\
(0.05-4.31)\end{array}$ & \\
Plasma & & $\begin{array}{c}12.59 \pm 11.48 \\
(\mathrm{nd}-38.76)\end{array}$ & \\
& 25 &
\end{tabular}

centrations in WW basis above the US EPA and Food and Drug Administration (FDA) recommended levels of human consumption $\left(0.3\right.$ and $1.0 \mathrm{mg} \mathrm{kg}^{-1} \mathrm{WW}$, respectively, US EPA 2001, US FDA 2020).

$\mathrm{THg}$ concentrations in muscle were significantly correlated with FL (Pearson's $r=0.6551, p=0.0005$, Fig. 2a). Significant correlations were also observed between FL and THg concentrations in fin (Pearson's $r=0.7233, p=0.0002$, Fig. 2b), red blood cells (Pearson's $\mathrm{r}=0.5544, \mathrm{p}=0.0074$, Fig. 2c), and plasma (Pearson's $\mathrm{r}=$ 0.5665, $\mathrm{p}=0.0032$, Fig. 2d). In contrast, muscle THg concentrations were not significantly correlated with muscle $\delta^{15} \mathrm{~N}$ (Pearson's $\mathrm{r}=0.1518, \mathrm{p}=0.479$, Fig. 3).

$\mathrm{THg}$ concentrations in muscle were significantly correlated with those in fin (Pearson's $r=0.8569$, $\mathrm{p}<$ 0.0001), red blood cells (Pearson's $r=0.5364, \mathrm{p}<$ 0.0148 ), and plasma (Pearson's $r=0.5916, p=0.0076$ ). However, of the three, fin was found to explain a greater proportion of the variation in muscle $\mathrm{THg}$ concentrations based on the results of linear regression analyses (Fig. 4).

Recent exposure to $\mathrm{Hg}$, as evaluated via the IRE, was significantly correlated with plasma $\delta^{15} \mathrm{~N}$ (Pearson's r $=0.590, p=0.0078$, Fig. 5).
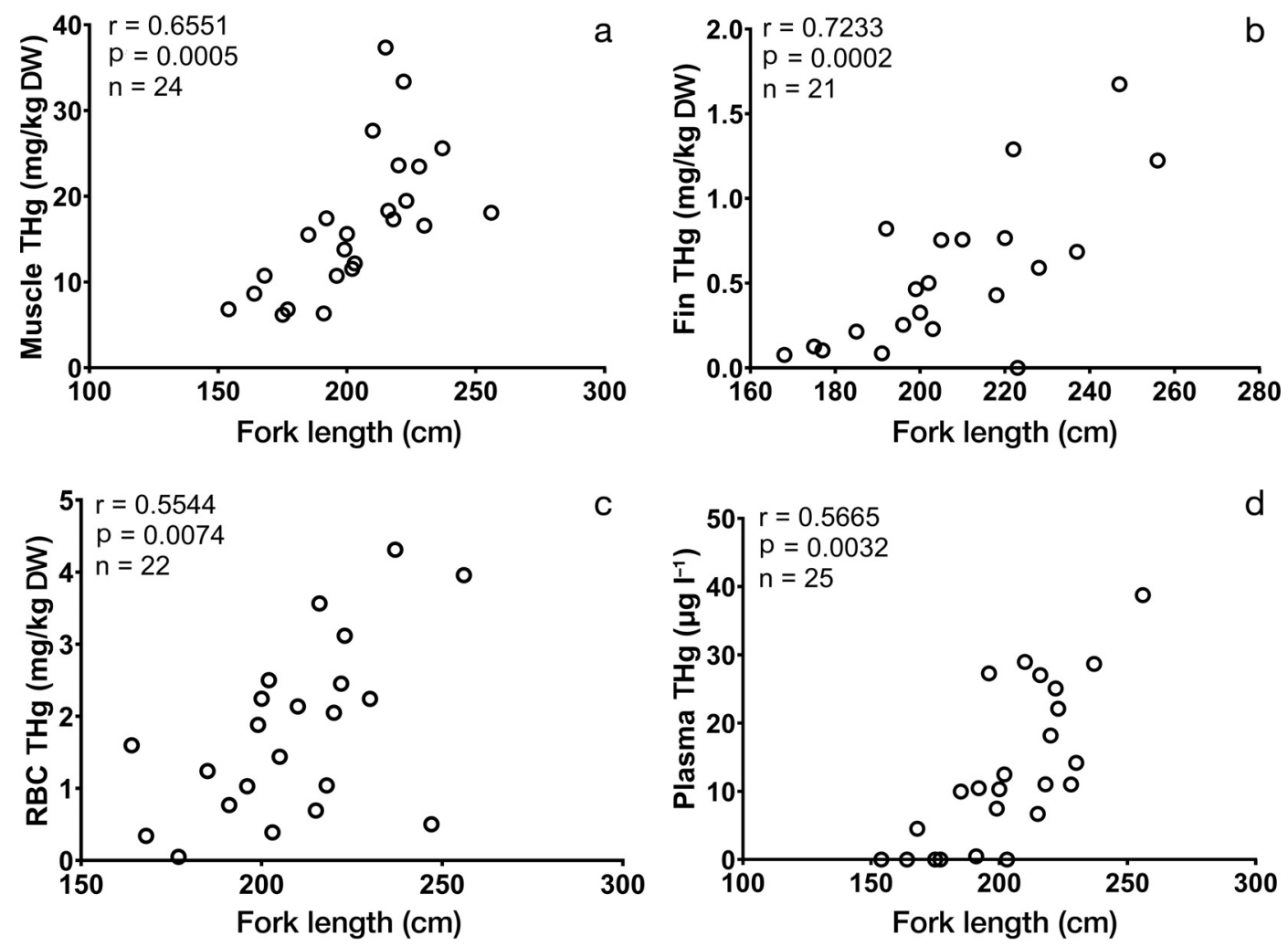

Fig. 2. Total mercury (THg) concentrations in (a) muscle, (b) fin, (c) red blood cells (RBC), and (d) plasma in relation to fork length in mature female oceanic whitetip sharks Carcharhinus longimanus from Cat Island, The Bahamas. Sample size (n) is shown for all datasets, along with results of correlation analysis conducted using Pearson's correlation coefficient 


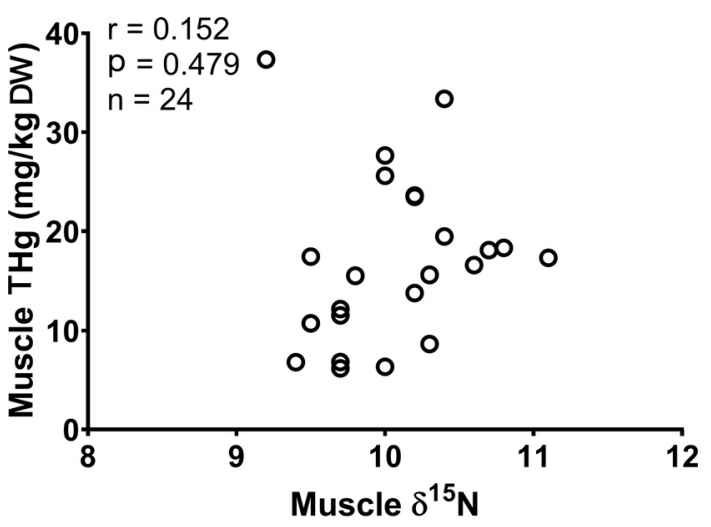

Fig. 3. Total mercury (THg) concentrations in muscle in relation to muscle $\delta^{15} \mathrm{~N}$ determined using stable isotope analysis in mature female oceanic whitetip sharks Carcharhinus longimanus from Cat Island, The Bahamas. Sample size (n) is shown, along with results of correlation analysis conducted using Pearson's correlation coefficient

\section{DISCUSSION}

The results of this study demonstrate that oceanic whitetip sharks can accumulate extremely high concentrations of $\mathrm{Hg}$, greater than many, if not most, other shark species. This is well illustrated by comparing muscle $\mathrm{THg}$ concentrations in Cat Island oceanic whitetip sharks $\left(5.04 \pm 2.52 \mathrm{mg} \mathrm{kg}^{-1} \mathrm{WW}\right)$ with concentrations previously reported in other large pelagic sharks from NWA waters, including shortfin makos, blue sharks Prionace glauca, common thresher sharks Alopias vulpinus, and porbeagle sharks Lamna nasus (Table 2). This is consistent with earlier studies on muscle THg levels in oceanic whitetip sharks from the Indian Ocean $\left(\sim 2 \mathrm{mg} \mathrm{kg}^{-1}\right.$ WW; Kiszka et al. 2015), which were also found to exceed concentrations observed in all other pelagic sharks examined, with the surprising and unexplained exception of the small-bodied crocodile shark Pseudocarcharias kamoharai (17.25 $\pm 6.45 \mathrm{mg} \mathrm{kg}^{-1}$ DW or $\sim 5 \mathrm{mg} \mathrm{kg}^{-1} \mathrm{WW}$; Kiszka et al. 2015). However, as described above, muscle THg concentrations observed in the present study greatly exceeded those observed in Indian Ocean oceanic whitetip sharks. To the authors' knowledge, only 4 shark species have been reported to exhibit muscle THg concentrations equal to or greater than those observed in Cat Island oceanic whitetip sharks: gulper sharks Centrophorus granulosus from Albania (9.09 \pm $0.83 \mathrm{mg} \mathrm{kg}^{-1}$ WW; Storelli et al. 2002), smooth hammerhead sharks Sphyrna zygaena from the Ionian Sea (16.06 $\pm 0.04 \mathrm{mg} \mathrm{kg}^{-1} \mathrm{WW}$; Storelli et al. 2002, $12.15 \pm 4.60 \mathrm{mg} \mathrm{kg}^{-1} \mathrm{WW}$; Storelli et al. 2003), young-
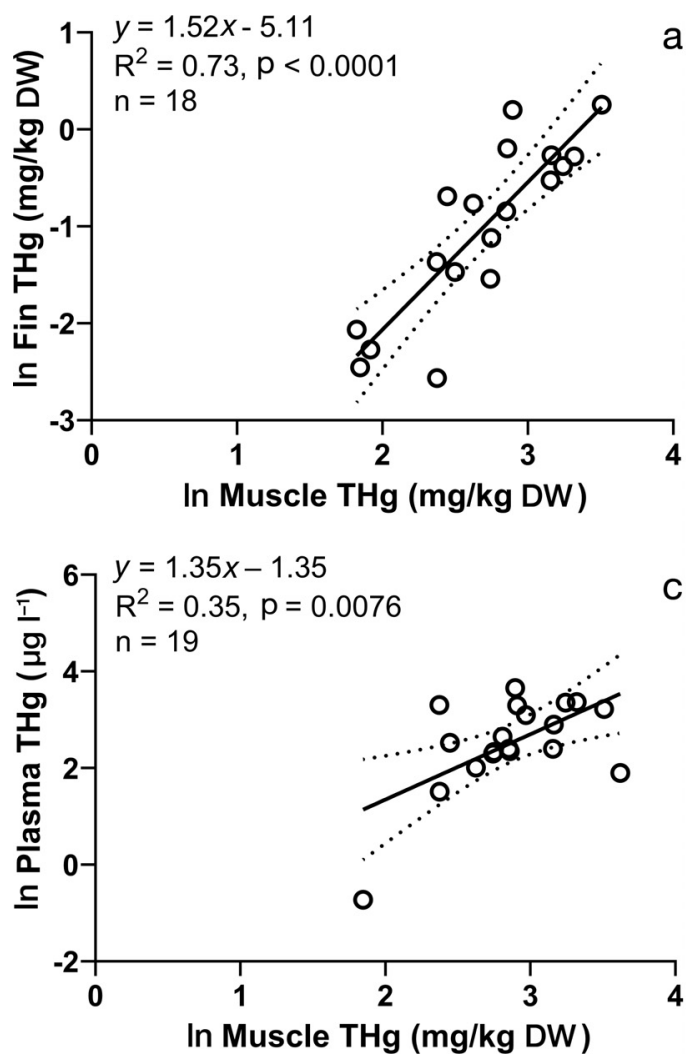

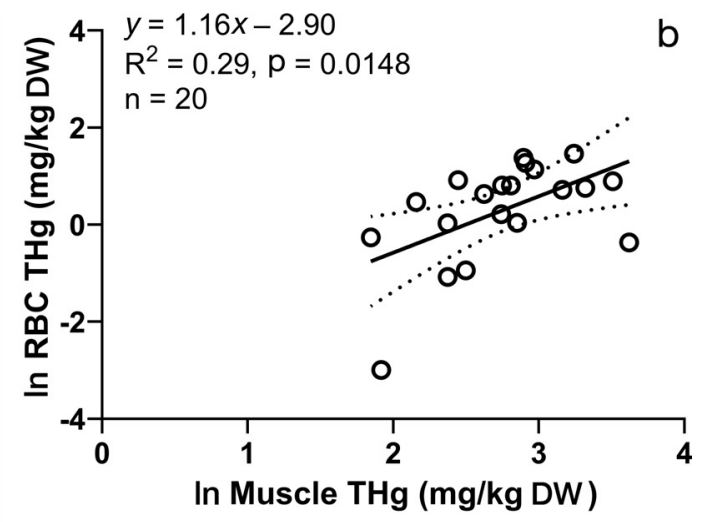

Fig. 4. Total mercury (THg) concentrations in (a) fin, (b) red blood cells (RBC), and (c) plasma in relation to muscle THg concentrations in mature female oceanic whitetip sharks Carcharhinus longimanus from Cat Island, The Bahamas. Sample size (n) is shown for all datasets, along with results of linear regression analysis. All data are natural log transformed. Solid line: linear relationships between the 2 variables; dotted lines: 95\% confidence intervals 


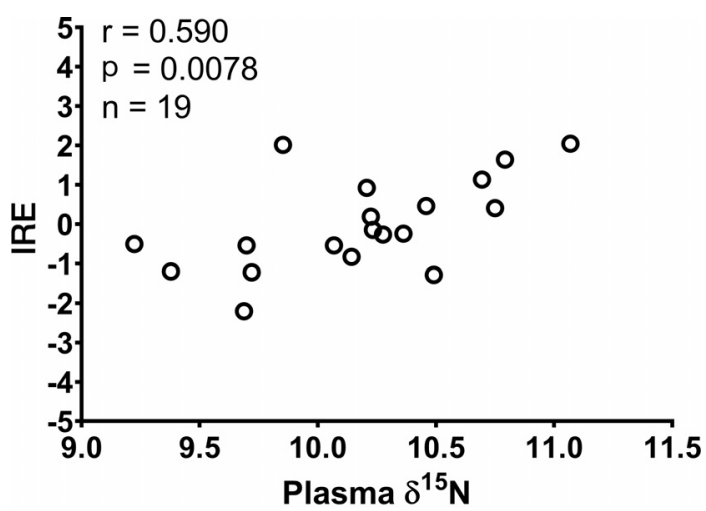

Fig. 5. Index of recent exposure (IRE) to $\mathrm{Hg}$ in relation to plasma $\delta^{15} \mathrm{~N}$ levels determined using stable isotope analysis in mature female oceanic whitetip sharks Carcharhinus longimanus from Cat Island, The Bahamas. Sample size (n) is shown, along with results of correlation analysis conducted using Pearson's correlation coefficient

of-the-year and juvenile white sharks from the Southern California Bight (range of 0.41-10.3 $\mathrm{mg} \mathrm{kg}^{-1} \mathrm{WW}$; Mull et al. 2012), and the aforementioned crocodile sharks from the Indian Ocean. This conclusion is based on extensive reviews of muscle $\mathrm{THg}$ concentrations in $>100$ elasmobranch species (reviewed in Gelsleichter \& Walker 2010, Bezerra et al. 2019); a point that underscores the novelty of the present results.

As commonly observed in most studies on $\mathrm{Hg}$ accumulation in sharks, animal length (FL in this study) was significantly correlated with muscle THg concentrations in Cat Island oceanic whitetip sharks. This may partly explain the elevated Hg concentrations reported in these individuals, particularly in comparison with smaller shark species, as it reflects a pattern of $\mathrm{Hg}$ accumulation in a relatively large-bodied and long-lived species. For example, based on comparisons of their size with prior growth rate estimates (Lessa et al. 1999), all sharks examined in the present study were likely to be greater than $10 \mathrm{yr}$ of age, a lengthy period of $\mathrm{Hg}$ accumulation. However, size and longevity are insufficient to explain the higher muscle $\mathrm{THg}$ concentrations observed in Cat Island oceanic whitetip sharks compared with those reported in other large pelagic sharks from NWA waters, as these species are also known to be relatively long-lived and grow to comparable sizes. Perhaps the best example of this is the shortfin mako, which has been shown to exhibit a similar maximum size and longevity (Natanson et al. 2006) as the oceanic whitetip shark; however, maximum muscle THg concentrations in NWA mako sharks still appear to fall below those in oceanic whitetips of a comparable size and, presumably, age.
Table 2. Total mercury concentrations ( $\mathrm{mg} \mathrm{kg}^{-1} \mathrm{WW}$ ) in muscle of pelagic sharks from northwest Atlantic waters

\begin{tabular}{|c|c|c|c|}
\hline Species & $\mathrm{n}$ & $\begin{array}{l}\text { Mean } \pm \mathrm{SD} \\
\text { (Range) }\end{array}$ & Reference \\
\hline $\begin{array}{l}\text { Common thresher } \\
\text { Alopias vulpinus }\end{array}$ & 41 & $\begin{array}{l}0.87 \pm 0.71 \\
(0.21-3.21)\end{array}$ & Teffer et al. (2014) \\
\hline $\begin{array}{l}\text { Oceanic whitetip } \\
\text { Carcharhinus } \\
\text { longimanus }\end{array}$ & 24 & $\begin{array}{c}5.04 \pm 2.52 \\
(1.86-11.20)\end{array}$ & This study \\
\hline $\begin{array}{l}\text { Shortfin mako } \\
\text { Isurus oxyrinchus }\end{array}$ & 32 & $\begin{array}{l}2.65 \pm 1.16 \\
(0.75-4.93)\end{array}$ & Teffer et al. (2014) \\
\hline $\begin{array}{l}\text { Porbeagle } \\
\text { Lamna nasus }\end{array}$ & 1 & 0.55 & $\begin{array}{l}\text { Beckett \& Freeman } \\
(1974)\end{array}$ \\
\hline $\begin{array}{l}\text { Blue shark } \\
\text { Prionace glauca }\end{array}$ & 14 & $\begin{array}{c}0.70 \\
(0.40-1.17)\end{array}$ & $\begin{array}{l}\text { Beckett \& Freeman } \\
(1974)\end{array}$ \\
\hline
\end{tabular}

An additional factor that may contribute to elevated $\mathrm{Hg}$ accumulation in oceanic whitetip sharks are their relatively high trophic position $(>4.0$, Cortés 1999) and the well-documented tendency for $\mathrm{Hg}$ to biomagnify in marine food webs (Lavoie et al. 2013). This may be particularly true for Cat Island oceanic whitetips, which have been shown to feed opportunistically on fish species (e.g. large pelagic teleosts, such as tunas, dolphinfish, and wahoo) that occupy higher trophic levels than their typical prey (e.g. squid, small pelagic fish) due to both intentional provisioning by dive boat operations as well as depredation of recreationally caught trophy fish (Madigan et al. 2015). Since some of these species, especially tuna species, are known to accumulate elevated quantities of $\mathrm{Hg}$ (Kumar 2018), this may represent an important source for $\mathrm{Hg}$ uptake. However, this too may not fully explain the greater THg levels in Cat Island oceanic whitetips compared with those reported in other large pelagic sharks, as several of these species have been shown to occupy similar if not higher trophic positions. This point is well supported by data from Kiszka et al. (2015), who found Indian Ocean oceanic whitetip sharks to exhibit lower rather than higher estimates of trophic position than those of several other large shark species (e.g. common thresher, shortfin mako, and the large, coastal and semi-pelagic scalloped hammerhead Sphyrna lewini) despite displaying higher muscle $\mathrm{THg}$ concentrations than these species. Similar results have been reported by Li et al. (2014), who found mid-east Pacific oceanic whitetip sharks to exhibit the lowest trophic position of 5 large shark species compared to blue shark, scalloped hammerhead, bigeye thresher 
Alopias superciliosus, and silky shark Carcharhinus falciformis.

As Hg accumulation is affected by trophic activity, it may appear surprising that we found no significant relationship between muscle $\mathrm{THg}$ concentrations and $\delta^{15} \mathrm{~N}$ in Cat Island oceanic whitetip sharks. However, it is important to note that this observation is common in the literature; in fact, out of the sizeable number of studies that have examined intraspecific relationships between $\mathrm{Hg}$ accumulation and $\delta^{15} \mathrm{~N}$-derived trophic position in chondrichthyans, only a third (20 out of 60 ) of these associations were found to be significantly correlated (Domi et al. 2005, Endo et al. 2009, 2013, 2015, 2016, Pethybridge et al. 2010, Newman et al. 2011, Rumbold et al. 2014, Taylor et al. 2014, Teffer et al. 2014, Kiszka et al. 2015, Kim et al. 2016, Matulik et al. 2017, Le Bourg et al. 2019). No studies to date have presented explanations for the conflicting results observed in these studies (other than low sample size; Pethybridge et al. 2010); however, Teffer et al. (2014) suggested that a lack of significant relationships between $\mathrm{Hg}$ concentrations and $\delta^{15} \mathrm{~N}$ in single species (referring specifically to dolphinfish Coryphaena hippurus, yellowfin tuna Thunnus albacares, and albacore tuna T. alalunga) could result from sampling a narrow size range. This could explain the lack of a significant correlation between these 2 variables in Cat Island oceanic whitetips, as all individuals sampled in the present study were mature females and presumably larger than the size at which major ontogenetic changes in diet occur in this species. This premise is supported by earlier observations on the relationship between muscle $\delta^{15} \mathrm{~N}$ and fork length in Cat Island oceanic whitetip sharks (different individuals, but comparable size range to those observed in the present study), which demonstrated only a moderate, non-significant positive relationship between the 2 variables in the life stages typically sampled from this location (Madigan et al. 2015).

Other factors that lead to greater $\mathrm{Hg}$ accumulation in Cat Island oceanic whitetip sharks compared to other NWA pelagic sharks could include differences in exposure related to dissimilar habitat use patterns and/or proximities to local point sources. Similarly, high ambient ocean temperatures at sub-tropical latitudes may drive higher bacterial methylation rates (Lee \& Fisher 2016), which may increase the initial loading of THg at the base of the food web. It is also possible that the lower $\mathrm{Hg}$ concentrations observed in endothermic species, such as shortfin mako and common thresher sharks, may reflect interspecific differences in $\mathrm{Hg}$ turnover related to metabolic rate. Although they are beyond the scope of the present study, these are interesting topics for future research.

Regardless of their cause, the high THg concentrations observed in muscle of NWA oceanic whitetip sharks greatly exceed global thresholds for human dietary purposes (>1.0 $\mathrm{mg} \mathrm{kg}^{-1} \mathrm{WW}$; Evers et al. 2018) and thus pose health risks to human consumers of meat from this species. This can include a variety of physiological responses, such as effects on central nervous system function, immunology, cardiovascular health and hematology, endocrinology, reproduction, and in pregnant women, fetal health (Rice et al. 2014). While such risks may be minimal for residents of countries that do not actively harvest oceanic whitetip meat for human consumption (e.g. the USA and The Bahamas), they may be greater for those residing in several Caribbean nations falling within the movement range of Cat Island oceanic whitetips (Howey-Jordan et al. 2013). This would include (but is not limited to) Cuba and Haiti, both of which are known to catch and consume juvenile oceanic whitetip sharks in small-scale artisanal fisheries (Aguilar et al. 2014, J. Aquino, Haiti Ocean Project, pers comm.). There are also some human health risks associated with consumption of oceanic whitetip shark fin as it holds a greater commercial value than meat in most countries and has been estimated to represent approximately $2 \%$ of the Hong Kong shark fin market, a long-time indicator of the global fin trade (Clarke et al. 2006). While THg concentrations observed in oceanic whitetip shark fin in both the present (nd to $1.68 \mathrm{mg} \mathrm{kg}^{-1} \mathrm{DW}$ ) and previous (0.1 to $0.791 \mathrm{mg} \mathrm{kg}^{-1}$ DW, Nalluri et al. 2014) studies were generally below consumption thresholds, it has been demonstrated that this species may exhibit higher fin THg levels than several other shark species and that up to approximately $70 \%$ of the $\mathrm{THg}$ in dried shark fin may be in the form of MeHg (Nalluri et al. 2014). Furthermore, by measuring $\mathrm{THg}$ and $\mathrm{MeHg}$ concentrations directly in commercially available shark fin soup, Nalluri et al. (2014) estimated that a standard $8 \mathrm{oz}$ (226.8 g) serving could alone approach levels comparable to the US EPA reference dose (RfD) of $0.1 \mu \mathrm{g}$ MeHg per kg body weight per day (Rice et al. 2003). This would raise the potential for exceedance of the RfD in cases when shark fin soup would be consumed with other, potentially Hg-rich, seafood products.

Along with the health risks posed to human consumers of oceanic whitetip products, there is also the possibility for physiological effects in these sharks and perhaps their offspring via maternal $\mathrm{Hg}$ transfer (Lyons et al. 2013), as muscle THg concentrations in all individuals examined in the present study ex- 
ceeded the estimated lowest-observed-adverse-effect level (LOAEL) for Hg-related effects in fish species (0.5 to $1.0 \mathrm{mg} \mathrm{kg}^{-1} \mathrm{WW}$ in axial muscle; Sandheinrich $\&$ Wiener 2011). Although such effects do not include lethality, which has generally only been reported at extremely high exposure levels (6 to $20 \mathrm{mg} \mathrm{kg}^{-1} \mathrm{WW}$; Wiener \& Spry 1996), it does include responses that would be detrimental to population health, such as neurobehavioral effects and reduction of reproductive fitness (e.g. Nacci et al. 2005, Evers et al. 2008, Goutte et al. 2014). For example, several studies have reported that exposure to and/or accumulation of $\mathrm{MeHg}$ can negatively affect a number of reproductive endpoints including gonadal steroidogenesis, gonadosomatic index, fertility, and/or reproductive behavior in males and females of various fish species at tissue residue levels slightly above the estimated LOAEL (e.g. catfish Clarias batrachus, Kirubagaran \& Joy 1992; killifish Fundulus heteroclitus, Matta et al. 2001; fathead minnow Pimephaes promelas, Hammerschmidt et al. 2002, Drevnick \& Sandheinrich 2003, Drevnick et al. 2006, Sandheinrich \& Miller 2006). These effects appear to be at least in part due to Hg-induced cell damage and/or death in the gonads, resulting in atrophy and/or atresia. If such effects were to occur in NWA oceanic whitetip sharks, it could negatively impact the growth and stability of already threatened populations. However, whether this is possible remains questionable because many shark species have been shown to accumulate $\mathrm{Hg}$ at levels well above the LOAEL without any apparent effects on health or reproduction (e.g. Matulik et al. 2017). Given this, it is likely that sharks exhibit higher thresholds for Hg-associated effects than other fishes, especially considering that the LOAEL is largely based on studies of $\mathrm{Hg}$ effects in freshwater teleosts. This may be because of lower distribution of $\mathrm{Hg}$ towards sensitive target organs; for example, previous studies have observed only low, presumably below-toxic levels of $\mathrm{Hg}$ in brain and gonads of sharks despite elevated muscle concentrations (Ehnert-Russo \& Gelsleichter 2020). It is also possible that selenium uptake may protect sharks from toxic effects through interactions with $\mathrm{Hg}$, forming biologically inert selenomercury complexes (Ganther et al. 1972, Cuvin-Aralar \& Furness 1991); however, more information is needed to confirm this often cited, but still poorly studied hypothesis.

As demonstrated by this study and previous research (Rumbold et al. 2014, Matulik et al. 2017, O'Bryhim et al. 2017), muscle biopsies provide an effective, non-lethal approach for assessing Hg exposure and uptake in sharks and their relatives.
Nonetheless, the present study also examined the potential use of fin biopsies as an alternative surrogate tissue for $\mathrm{Hg}$ analysis in sharks and found THg concentrations in these samples to be a good predictor of muscle THg levels in oceanic whitetip sharks. Significant correlations were also found between THg concentrations in fin and axial muscle in the bonnethead Sphyrna tiburo, but not silky shark by O'Bryhim et al. (2017); however, the authors proposed that species-specific variations may have been a function of differences in sample size. While muscle is clearly the preferred tissue for Hg screening in sharks, there are certain situations in which fin may be easier to obtain, justifying the need for a better understanding of the relationship between $\mathrm{Hg}$ levels in fin and other tissues. A good example of this would be for toxicological studies on very large elasmobranchs, which can often exhibit epidermal and subepidermal layers up to a combined 2 to $3 \mathrm{~cm}$ in thickness, complicating efforts to obtain sufficient amounts of underlying muscle for analysis (JaimeRivera et al. 2013, Rohner et al. 2013, Meyer et al. 2017). The greater ease of this sampling approach may also be useful for facilitating large-scale studies of geographical variations in Hg exposure in sharks, perhaps even by involving recreational anglers as citizen scientists (Williams et al. 2015).

Although commonly used for assessing Hg exposure in humans (Berglund et al. 2005, Basu et al. 2018) and some animal taxa, such as turtles and seabirds (Day et al. 2005, Hopkins et al. 2013, Evers 2018, Perrault et al. 2019), Hg concentrations in red blood cells of sharks have not (to the best of the authors' knowledge) been previously reported. Like those in fin, this study found THg concentrations in oceanic whitetip red blood cells to be significantly correlated with those in muscle. However, the strength of this association was weaker than that between fin and muscle, making red blood cell THg concentrations a less effective predictor of muscle Hg levels. Nonetheless, THg levels in red blood cells may provide a unique approach for evaluating short-term exposure to Hg in sharks as the Hg signature in vertebrate blood is generally believed to represent a combination of recent (days to weeks) Hg exposure along with a more stable component, reflecting historical Hg accumulation (Day et al. 2005). With this in mind, we followed the approach of Day et al. (2005) and used the IRE as an indicator of recent Hg uptake relative to long-term accumulation patterns in individual sharks and found it to be significantly correlated with plasma $\delta^{15} \mathrm{~N}$, an indicator of recent trophic activity. This suggests that differences in recent feed- 
ing activity in Cat Island oceanic whitetip sharks may explain variations in red blood cell THg levels, and eventually contribute to possible differences in longterm accumulation patterns. Although it could not be accomplished in the present study since all animals were collected from the same general location, future studies should compare $\mathrm{THg}$ concentrations in both muscle and red blood cell samples from sharks collected from different basins within a small geographical region to determine if measurements in red blood cells would provide a more specific characterization of individual $\mathrm{Hg}$ exposure and site-specific levels of $\mathrm{Hg}$ contamination. This would be comparable to the work conducted by Day et al. (2005), who found a significant correlation between the IRE and proximity of capture site to the nearest major river mouth in loggerhead sea turtle Caretta caretta, suggesting that variations in recent $\mathrm{Hg}$ exposure were at least partly related to differences in individual movement patterns and/or regional exposure levels.

As a large proportion (80 to $90 \%$ ) of $\mathrm{Hg}$ found in vertebrate blood generally occurs in red blood cells due to its tendency to bind to hemoglobin, measurements of $\mathrm{Hg}$ concentrations in plasma are rarely taken, even in human toxicology studies (Nuttall 2004). Despite this, the current study examined THg concentrations in oceanic whitetip shark plasma and their association with muscle THg levels, mainly to better understand the toxicological relevance of plasma Hg levels in sharks and their relatives. This was motivated by a recent study on plasma heavy metal levels in white sharks, which reported high, potentially toxic plasma $\mathrm{THg}$ concentrations in this species (range $=36.0-265.5 \mu \mathrm{g} \mathrm{l}^{-1}$, Merly et al. 2019). However, since muscle THg concentrations were not measured by Merly et al. (2019), the toxicological significance of their findings remains uncertain. The results of the current study showed that THg concentrations in oceanic whitetip plasma and muscle were significantly correlated, suggesting that plasma $\mathrm{Hg}$ concentrations in sharks may at least partly reflect long-term $\mathrm{Hg}$ accumulation patterns and the potential for toxicological responses. It is hypothesized that the much greater levels of $\mathrm{Hg}$ in plasma of sharks, such as those observed by Merly et al. (2019) for white sharks and those described herein for oceanic whitetip sharks, compared with those in humans (typically below $1.0 \mathrm{\mu g} \mathrm{l}^{-1}$ in the general population, Ganss et al. 2000, Berglund et al. 2005) reflects the greater and more regular consumption of relatively MeHg-rich prey. Future work should compare blood (total blood or red blood cells) or plasma THg concentrations in sharks with different dietary habits (e.g. trophic level, feeding regularity) to determine if patterns reflect such differences, much in the way that occupational exposure and other behaviors (e.g. seafood consumption) influence human $\mathrm{Hg}$ burden.

\section{CONCLUSIONS}

In summary, the present study augments previous work suggesting high $\mathrm{Hg}$ accumulation in the Critically Endangered oceanic whitetip shark by demonstrating that Cat Island, Bahamas, individuals accumulate some of the highest levels of $\mathrm{THg}$ ever reported in a shark species. We observed significant correlations between THg concentrations in muscle and various surrogate tissues, potentially yielding valuable new approaches for assessing various aspects of $\mathrm{Hg}$ uptake and distribution in sharks and their relatives. Future studies should use these and other approaches, especially indicators of toxicity, to determine if elevated $\mathrm{Hg}$ exposure affects the health of oceanic whitetip sharks in a manner that would limit the recovery of these already highly imperiled populations.

Acknowledgements. The authors acknowledge the following individuals for their contributions to this study: D. Abercrombie, A. Brooks, M. Bond, D. Chapman, L. Jordan, S. Williams, J. Kneebone, R. Knotek, J. Mandelman, C. Shields, M. Winchester, J. Salamone, S. Genereux, T. Bacon, A. Colley, and G. Henkes. We also thank the Cape Eleuthera Institute staff and interns for help with field logistics. Funding was provided by the Moore Charitable Foundation and private grants to the Cape Eleuthera Island School Foundation.

\section{LITERATURE CITED}

Aguilar C, Gonzalez-Sanson G, Hueter R, Rojas E and others (2014) Shark catches in the northwest region of Cuba. Lat Am J Aquat Res 42:477-487

Basu N, Horvat M, Evers D, Zastenskaya I, Weihe P, Tempowski J (2018) A state-of-the-science review of mercury biomarkers in human populations worldwide between 2000 and 2018. Environ Health Perspect 126:106001

Beckett JS, Freeman HC (1974) Mercury in swordfish and other pelagic species from the western Atlantic Ocean. Proceedings of the International Billfish Symposium, Kailua-Kona, Hawaii, 9-12 August 1972. Part 2. Review and Contributed Papers. NOAA Tech Rep NMFS-SSRF675 (1974), p 154-159

* Bergés-Tiznado ME, Márquez-Farías F, Lara-Mendoza RE, Torres-Rojas YE, Galván-Magaña F, Bojórquez-Leyva $\mathrm{H}_{\text {, }}$ Páez-Osuna F (2015) Mercury and selenium in muscle and target organs of scalloped hammerhead sharks Sphyrna lewini of the SE Gulf of California: dietary intake, molar ratios, loads, and human health risks. Arch Environ Contam Toxicol 69:440-452

* Berglund M, Lind B, Björnberg K, Palm B, Einarsson O, Vahter M (2005) Inter-individual variations of human 
mercury exposure biomarkers: a cross-section assessment. Environ Health 4:20

Bezerra MF, Lacerda LD, Lai CT (2019) Trace metals and persistent organic pollutants contamination in batoids (Chondrichthyes: Batoidea): a systematic review. Environ Pollut 248:684-695

Biton-Porsmoguer S, Banaru D, Boudouresque C, Dekeyser I and others (2018) Mercury in blue shark (Prionace glauca) and shortfin mako (Isurus oxyrinchus) from north-eastern Atlantic: implication for fishery management. Mar Pollut Bull 127:131-138

* Bosch AC, O'Neill B, Sigge GO, Kerwath SE, Hoffman LC (2016) Heavy metals in marine fish meat and consumer health: a review. J Sci Food Agric 96:32-48

*Byrne ME, Cortés E, Vaudo JJ, Harvey GCM, Sampson M, Wetherbee BM, Shivji M (2017) Satellite telemetry reveals higher fishing mortality rates than previously estimated, suggesting overfishing of an apex marine predator. Proc R Soc B 284:20170658

Campana SE, Marks L, Joyce W (2005) The biology and fishery of shortfin mako sharks (Isurus oxyrinchus) in Atlantic Canadian waters. Fish Res 73:341-352

* Carlisle AB, Litvin SY, Madigan DJ, Lyons K, Bigman JS, Ibarra M, Bizzarro JJ (2017) Interactive effects of urea and lipid content confound stable isotope analysis in elasmobranch fishes. Can J Fish Aquat Sci 74:419-428

Clark E, von Schmidt K (1965) Sharks of the central Gulf coast of Florida. Bull Mar Sci 15:13-83

* Clarke SC, McAllister M, Milner-Gulland E, Kirkwood G and others (2006) Global estimates of shark catches using trade records from commercial markets. Ecol Lett 9:1115-1126

* Cortés E (1999) Standardized diet compositions and trophic levels of sharks. ICES J Mar Sci 56:707-717

* Cuvin-Aralar MLA, Furness RW (1991) Mercury and selenium interaction: a review. Ecotoxicol Environ Saf 21: 348-364

Nay RD, Christopher SJ, Becker PR, Whitaker DW (2005) Monitoring mercury in the loggerhead sea turtle, Caretta caretta. Environ Sci Technol 39:437-446

Domi N, Bouquegneau JM, Das K (2005) Feeding ecology of five commercial shark species of the Celtic Sea through stable isotope and trace metal analysis. Mar Environ Res 60:551-569

* Drevnick PE, Sandheinrich MB (2003) Effects of dietary methylmercury on reproductive endocrinology of fathead minnows. Environ Sci Technol 37:4390-4396

* Drevnick PE, Sandheinrich MB, Oris JT (2006) Increased ovarian follicular apoptosis in fathead minnows (Pimephales promelas) exposed to dietary methylmercury. Aquat Toxicol 79:49-54

* Dulvy NK, Baum JK, Clarke S, Compagno LJV and others (2008) You can swim but you can't hide: the global status and conservation of oceanic pelagic sharks and rays. Aquat Conserv 18:459-482

Ehnert-Russo SL, Gelsleichter J (2020) Mercury accumulation and effects in the brain of the Atlantic sharpnose shark (Rhizoprionodon terraenovae). Arch Environ Contam Toxicol 78:267-283

* Endo T, Hisamichi Y, Kimura O, Kotaki Y and others (2009) Contamination levels of mercury in the muscle of female and male spiny dogfishes (Squalus acanthias) caught off the coast of Japan. Chemosphere 77:1333-1337

Endo T, Hisamichi Y, Kimura O, Ogasawara H and others (2013) Levels of mercury in muscle and liver of star-spot- ted dogfish (Mustelus manazo) from the northern region of Japan: a comparison with spiny dogfish (Squalus acanthias). Arch Environ Contam Toxicol 64:467-474

* Endo T, Kimura O, Ogasawara H, Ohta O, Koga N, Kato Y, Haraguchi K (2015) Mercury, cadmium, zinc and copper concentrations and stable isotope ratios of carbon and nitrogen in tiger sharks (Galeocerdo cuvier) culled off Ishigaki Island, Japan. Ecol Indic 55:86-93

* Endo T, Kimura O, Ohta C, Koga N, Kato Y, Fujii Y, Haraguchi K (2016) Metal concentrations in the liver and stable isotope ratios of carbon and nitrogen in the muscle of silvertip shark (Carcharhinus albimarginatus) culled off Ishigaki Island, Japan: changes with growth. PLOS ONE 11:e0147797

Evers D (2018) The effects of methylmercury on wildlife: a comprehensive review and approach for interpretation. In: DellaSala DA, Goldstein MI (eds) The encyclopedia of the Anthropocene, Vol. 5. Elsevier, Oxford, p 181-194

* Evers DC, Savoy LJ, DeSorbo CR, Yates DE and others (2008) Adverse effects from environmental mercury loads on breeding common loons. Ecotoxicology 17: 69-81

Evers DC, Taylor M, Burton M, Johnson S (2018) Mercury in the global environment: understanding spatial patterns for biomonitoring needs of the Minamata Convention on Mercury. BRI Science Communications Series 2018-21. Biodiversity Research Institute, Portland, ME

Ganss C, Gottwald B, Traenckner I, Kupfer J and others (2000) Relation between mercury concentrations in saliva, blood, and urine in subjects with amalgam restorations. Clin Oral Investig 4:206-211

*Ganther HE, Goudie C, Sunde ML, Kopecky MJ, Wagner P, Oh SH, Hoekstra WG (1972) Selenium: relation to decreased toxicity of methylmercury added to diets containing tuna. Science 175:1122-1124

Gelsleichter J, Walker CJ (2010) Pollutant exposure and effects in sharks and their relatives. In: Carrier JC, Musick JA, Heithaus MR (eds) Sharks and their relatives II: biodiversity, adaptive physiology, and conservation. CRC Press, Boca Raton, FL, p 491-540

KGoutte A, Bustamante P, Barbraud C, Delord K, Weimerskirch H, Chastel O (2014) Demographic responses to mercury exposure in two closely related Antarctic top predators. Ecology 95:1075-1086

*Hammerschmidt CR, Sandheinrich MB, Wiener JG, Rada RG (2002) Effects of dietary methylmercury on reproduction of fathead minnows. Environ Sci Technol 36: $877-883$

* Hopkins BC, Hepner MJ, Hopkins WA (2013) Non-destructive techniques for biomonitoring of spatial, temporal, and demographic patterns of mercury bioaccumulation and maternal transfer in turtles. Environ Pollut 177: $164-170$

* Howey LA, Tolentino ER, Papastamatiou YP, Brooks EJ and others (2016) Into the deep: the functionality of mesopelagic excursions by an oceanic apex predator. Ecol Evol 6:5290-5304

*Howey-Jordan LA, Brooks EJ, Abercrombie DL, Jordan LK and others (2013) Complex movements, philopatry and expanded depth range of a severely threatened pelagic shark, the oceanic whitetip (Carcharhinus longimanus) in the western North Atlantic. PLOS ONE 8:e56588

Jaime-Rivera M, Caraveo-Patiño J, Hoyos-Padilla M, GalvánMagaña F (2013) Evaluation of biopsy systems for sam- 
pling white shark Carcharodon carcharias (Lamniformes: Lamnidae) muscle for stable isotope analysis. Rev Biol Mar Oceanogr 48:345-351

Kim SL, Koch PL (2012) Methods to collect, preserve, and prepare elasmobranch tissues for stable isotope analysis. Environ Biol Fishes 95:53-63

Kim SJ, Lee HK, Badejo AC, Lee WC, Moon HB (2016) Species-specific accumulation of methyl and total mercury in sharks from offshore and coastal waters of Korea. Mar Pollut Bull 102:210-215

Kirubagaran R, Joy KP (1992) Toxic effects of mercury on testicular activity in the freshwater teleost, Clarias batrachus (L.). J Fish Biol 41:305-315

Kiszka JJ, Aubail A, Hussey NE, Heithaus MR, Caurant F, Bustamante P (2015) Plasticity of trophic interactions among sharks from the oceanic south-western Indian Ocean revealed by stable isotope and mercury analyses. Deep Sea Res I 96:49-58

Kumar G (2018) Mercury concentrations in fresh and canned tuna: a review. Rev Fish Sci Aquacult 26:111-120

Lavoie RA, Jardine TD, Chumchal MM, Kidd KA, Campbell LM (2013) Biomagnification of mercury in aquatic food webs: a worldwide meta-analysis. Environ Sci Technol 47:13385-13394

Le Bourg B, Kiszka JJ, Bustamante P, Heithaus MR, Jaquemet S, Humber F (2019) Effect of body length, trophic position and habitat use on mercury concentrations of sharks from contrasted ecosystems in the southwestern Indian Ocean. Environ Res 169:387-395 doi:10.1016/j. envres.2018.11.024

Lee CS, Fisher NS (2016) Methylmercury uptake by diverse marine phytoplankton. Limnol Oceanogr 61:1626-1639

Lessa R, Santana FM, Paglerani R (1999) Age, growth and stock structure of the oceanic whitetip shark, Carcharhinus longimanus, from the southwestern equatorial Atlantic. Fish Res 42:21-30

* Li Y, Gong Y, Chen X, Dai X, Zhu J (2014) Trophic ecology of sharks in the mid-east Pacific Ocean inferred from stable isotopes. J Ocean Univ China 13:278-282

Lyons K, Carlisle A, Preti A, Mull C and others (2013) Effects of trophic ecology and habitat use on maternal transfer of contaminants in four species of young of the year lamniform sharks. Mar Environ Res 90:27-38

* Madigan DJ, Brooks EJ, Bond ME, Gelsleichter J and others (2015) Diet shift and site-fidelity of oceanic whitetip sharks Carcharhinus longimanus along the Great Bahama Bank. Mar Ecol Prog Ser 529:185-197

Matta MB, Linse J, Cairncross C, Francendese L, Kocan RM (2001) Reproductive and transgenerational effects of methylmercury or Aroclor 1268 on Fundulus heteroclitus. Environ Toxicol Chem 20:327-335

Matulik AG, Kerstetter DW, Hammerschlag N, Divoll T, Hammerschmidt CR, Evers DC (2017) Bioaccumulation and biomagnification of mercury and methylmercury in four sympatric coastal sharks in a protected subtropical lagoon. Mar Pollut Bull 116:357-364

Merly L, Lange L, Meÿer M, Hewitt AM and others (2019) Blood plasma levels of heavy metals and trace elements in white sharks (Carcharodon carcharias) and potential health consequences. Mar Pollut Bull 142:85-92

Meyer L, Pethybridge H, Nichols PD, Beckmann C, Bruce BD, Werry JM, Huveneers C (2017) Assessing the functional limitations of lipids and fatty acids for diet determination: the importance of tissue type, quantity, and quality. Front Mar Sci 4:369
Mull CG, Blasius ME, O'Sullivan JB, Lowe CG (2012) Heavy metals, trace elements, and organochlorine contaminants in muscle and liver tissue of juvenile white sharks, Carcharodon carcharias, from the Southern California Bight. In: Domeier ML (ed) Global perspectives on the biology and life history of the white shark. CRC Press, New York, NY, p 59-75

Nacci D, Pelletier M, Lake J, Bennett R and others (2005) An approach to predict risks to wildlife populations from mercury and other stressors. Ecotoxicology 14:283-293

Nalluri D, Baumann Z, Abercrombie D, Chapman D, Hammerschmidt C, Fisher N (2014) Methylmercury in dried shark fins and shark fin soup from American restaurants. Sci Total Environ 496:644-648

*Nam DH, Adams DH, Reyier EA, Basu N (2011) Mercury and selenium levels in lemon sharks (Negaprion brevirostris) in relation to a harmful red tide event. Environ Monit Assess 176:549-559

Natanson LJ, Kohler NE, Ardizzone D, Cailliet GM, Wintner SP, Mollet HF (2006) Validated age and growth estimates for the shortfin mako, Isurus oxyrinchus, in the North Atlantic Ocean. Environ Biol Fishes 77:367-383

* Newman MC, Xu X, Cotton CF, Tom KR (2011) High mercury concentrations reflect trophic ecology of three deepwater chondrichthyans. Arch Environ Contam Toxicol 60:618-625

*Nuttall KL (2004) Interpreting mercury in blood and urine of individual patients. Ann Clin Lab Sci 34:235-250

* O'Bryhim JR, Adams DH, Spaet JLY, Mills G, Lance SL (2017) Relationships of mercury concentrations across tissue types, muscle regions and fins for two shark species. Environ Pollut 223:323-333

* Perrault JR, Lehner AF, Buchweitz JP, Page-Karjian A (2019) Evidence of accumulation and elimination of inorganic contaminants from the lachrymal salt glands of leatherback sea turtles (Dermochelys coriacea). Chemosphere 217:59-67

* Pethybridge H, Cossa D, Butler ECV (2010) Mercury in 16 demersal sharks from southeast Australia: biotic and abiotic sources of variation and consumer health implications. Mar Environ Res 69:18-26

* Rice DC, Schoeny R, Mahaffey K (2003) Methods and rationale for derivation of a reference dose for methylmercury by the U.S. EPA. Risk Anal 23:107-115

* Rice KM, Walker EM Jr, Wu M, Gillette C, Blough ER (2014) Environmental mercury and its toxic effects. J Prev Med Public Health 47:74-83

Rigby CL, Barreto R, Carlson J, Fernando D and others (2019) Carcharhinus longimanus. The IUCN Red List of Threatened Species 2019: e.T39374A2911619. doi: 10.2305/IUCN.UK.2019-3.RLTS.T39374A2911619.en (accessed 23 March 2020)

Rohner CA, Couturier LIE, Richardson AJ, Pierce SJ, Prebble CEM, Gibbons MJ, Nichols PD (2013) Diet of whale sharks Rhincodon typus inferred from stomach content and signature fatty acid analyses. Mar Ecol Prog Ser 493:219-235

Rollin BE, Kessel ML (1997) Guidelines for the treatment of animals in behavioural research and teaching. Anim Behav 55:251-257

* Rumbold D, Wasno R, Hammerschlag N, Volety A (2014) Mercury accumulation in sharks from the coastal waters of southwest Florida. Arch Environ Contam Toxicol 67: 402-412

* Sandheinrich MB, Miller KM (2006) Effects of dietary methylmercury on reproductive behavior of fathead 
minnows (Pimephales promelas). Environ Toxicol Chem 25:3053-3057

Sandheinrich MB, Wiener JG (2011) Methylmercury in freshwater fish: recent advances in assessing toxicity of environmentally relevant exposures. In: Beyer WN, Meador JP (eds) Environmental contaminants in biota: interpreting tissue concentrations, 2nd edn. CRC Press/ Taylor and Francis, Boca Raton, FL, p 170-190

Shipley ON, Olin JA, Polunin NV, Sweeting CJ and others (2017) Polar compounds preclude mathematical lipid correction of carbon stable isotopes in deep-water sharks. J Exp Mar Biol Ecol 494:69-74

Storelli MM, Giacominelli-Stuffler R, Marcotrigiano G (2002) Mercury accumulation and speciation in muscle tissue of different species of sharks from Mediterranean Sea, Italy. Bull Environ Contam Toxicol 68:201-210

Storelli MM, Ceci E, Storelli A, Marcotrigiano GO (2003) Polychlorinated biphenyl, heavy metal and methylmercury residues in hammerhead sharks: contaminant status and assessment. Mar Pollut Bull 46:1035-1039

Taylor DL, Kutil NJ, Malek AJ, Collie JS (2014) Mercury bioaccumulation in cartilaginous fishes from Southern New England coastal waters: contamination from a trophic ecology and human health perspective. Mar Environ Res 99:20-33

Teffer AK, Staudinger MD, Taylor DL, Juanes F (2014) Trophic influences on mercury accumulation in top pelagic predators from offshore New England waters of the northwest Atlantic Ocean. Mar Environ Res 101:124-134

Tolotti MT, Bach P, Hazin F, Travassos P, Dagorn L (2015) Vulnerability of the oceanic whitetip shark to pelagic longline fisheries. PLOS ONE 10:e0141396

US EPA (Environmental Protection Agency) (2001) Water quality criteria for the protection of human health: methylmercury. EPA-823-R-01-001. Office of Science and

Editorial responsibility: Sandra Hochscheid, Naples, Italy
Technology, Office of Water, US Environmental Protection Agency, Washington, DC

US EPA (2007) Method 7473: mercury in solids and solutions by thermal decomposition, amalgamation, and atomic absorption spectrophotometry. US Environmental Protection Agency, Washington, DC

US FDA (Food and Drug Administration) (2020) Fish and fishery products hazards and controls guide, 4th edn. Department of Health and Human Services, Public Health Service, Center for Food Safety and Applied Nutrition, Office of Seafood, Washington, DC. www.fda.gov/food/ seafood-guidance-documents-regulatory-information/ fish-and-fishery-products-hazards-and-controls (accessed 25 March 2020)

Weideli OC, Kiszka JJ, Matich P, Heithaus MR (2019) Effects of anticoagulants on stable-isotope values $\left(\delta^{13} \mathrm{C}\right.$ and $\delta^{15} \mathrm{~N}$ ) of shark blood components. J Fish Biol 95: 1535-1539

Wiener JG, Spry DJ (1996) Toxicological significance of mercury in freshwater fish. In: Beyer WN, Heinz GH, Redmon-Norwood AW (eds) Environmental contaminants in wildlife-interpreting tissue concentrations. Lewis Publishers, Boca Raton, FL, p 297-339

Williams SM, Holmes BJ, Pepperell JG (2015) The novel application of non-lethal citizen science tissue sampling in recreational fisheries. PLOS ONE 10:e0135743

* Young CN, Carlson JK (2020) The biology and conservation status of the oceanic whitetip shark (Carcharhinus longimanus) and future directions for recovery. Rev Fish Biol Fish 30:293-312

Zillioux E (2015) Mercury in fish: history, sources, pathways, effects, and indicator usage. In: Armon RH, Hänninen O (eds) Environmental indicators. Springer, New York, NY, p 743-766

Submitted: April 16, 2020; Accepted: July 27, 2020

Proofs received from author(s): October 22, 2020 